\title{
Dissemination of the fit and proper test regarding the appointment of the Board of Directors of the Tangerang Regency Regional Company (PERUMDAM)
}

\author{
Mas Iman Kusnandar ${ }^{1^{*}}$,Refi Pratiwi ${ }^{2}$, Muhammad Abduh ${ }^{3}$ \\ 1,2,3 University of Sultan Ageng Tirtayasa, Indonesia \\ drmasimankusnandar@gmail.com ${ }^{\left.1^{*}\right)}$
}

\begin{abstract}
Abstrak
Kegiatan sosialisasi ini bertujuan untuk mengenalkan Uji Kelayakan dan Uji Kepatutan kepada peserta calon Direksi Perumdam Kabupaten Tangerang sebelum Uji Kelayakan dan Uji Kepatutan dilaksanakan. Uji Kelayakan dan Uji Kepatutan untuk menjaga independensi perusahaan. Metode pelaksanaan kegiatan dalam penerimaan calon anggota Direksi terdiri dari beberapa tahapan, mulai dari seleksi administrasi, seleksi Uji Kelayakan dan Uji Kepatutan, tes wawancara. Kegiatan sosialisasi ini wajib dilakukan setiap kali akan dilaksanakan Uji Kelayakan dan Uji Kepatutan karena masih terdapat risiko terkait kurangnya pemahaman tentang teknis Uji Kelayakan dan Uji Kepatutan.
\end{abstract}

Kata kunci: Uji kelayakan dan kepatutan, Perusahaan Daerah, Direksi

\begin{abstract}
This socialization activity aims to introduce the Fit and Proper Test to participants of the prospective Board of Directors of Perumdam Tangerang Regency before the Feasibility and Fit Test is held. Feasibility Test and Proper Test to maintain the independence of the company. The method of implementing activities in the acceptance of prospective candidates for the Board of Directors consists of several stages, namely starting from administrative selection, selection of fit and proper test, interview test. This socialization activity must be carried out every time a Feasibility and Fit Test will be carried out because there is still a risk regarding a lack of understanding of the technicalities of the Fit and Proper Test. With the fit and proper test, it produces leaders who are intellectually competent as well as cognitive and emotional.
\end{abstract}

Keywords: Feasibility Test and Fit Test, Regional Company, Board of Directors

\section{Introduction}

The top management organizational system in Indonesia has separated the board of directors and the board of commissioners. The board of directors is the party that runs the company's operations, while the board of commissioners is the party that supervises (including giving advice/suggestions) to the board of directors so that the company's operations can run in accordance with the vision and mission.

The theory put forward by Fama (1980) and Fama \& Jensen (1983) related to the composition of the board of directors is that the higher the composition of the board of directors from non-management will increase the effectiveness of the board in controlling 
operational management. The more effective the company's control, the more strategic decisions taken will benefit the company's performance.

Board of directors from non-management as "independent directors" and "grey directors". Independent Directors are directors who come from outside the company and have no affiliation/relationship with the company and with other boards of directors. While gray directors are directors who come from outside the company and may have affiliations with other directors within the company. This category of directors has the possibility of causing problems due to affiliation with management. With the Feasibility Test and the Fit Test, it gives the company independence because it involves a third party.

The potential of Regional Companies in Tangerang Regency is quite promising, how is the number one water company in Indonesia, the Tirta Kerta Raharja Regional Public Water Company (Perumdam TKR) of Tangerang Regency again ranked first out of 380 more similar companies in Indonesia in 2021, ranking the best water company in the world. Indonesia .

The achievement of the Tangerang Regency Government company which was founded in the colonial era (1923) under the name Water Leideng Bedryf was achieved based on a performance assessment by the Ministry of Public Works and Public Housing, Directorate General of Human Settlements, Directorate of Drinking Water for 2020.

Until now, the Tangerang Regency water company has tried many breakthroughs in the Covid pandemic era to facilitate services during a pandemic, for example with a simple application that can be downloaded on the appstore and iOS that facilitates service information up to payment. Perumdam TKR is also innovating with the Digitalization of Data and Services, for example smart metering (Digital Water Meters). Perumdam TKR, which since July 2020 has been led by Sofyan Safar as President Director, achieved a healthy performance score with a score of 4.28 , an increase of one point from the previous year. Sofyan Safar's performance deserves a thumbs up. This is inseparable from the recruitment of the TKR Perumdam Board of Directors through the Feasibility and Fit Test conducted by several academics from Sultan Ageng Tirtayasa University.

The legal basis for the Fit and Proper Test (UKK) is a letter from the chairman of the panel for prospective members of the Supervisory Board of Perumdam Tirta Kerta Raharja Tangerang Regency Number 03/PANSEL-X/2020, dated 19 October regarding the application to become an expert team for the Fit and Proper Test (UKK) to be candidate for the Supervisory Board of the Tirta Kerta Raharja Regional Public Drinking Water Company, Tangerang Regency. The UKK is based on Permendagri Number 37 of 2018 concerning the appointment and dismissal of supervisory members or members of commissioners and members of the Board of Directors of Regional Owned Enterprises including Psychological Tests, Written Skills Examinations, Writing Papers, Supervision Strategies and Presentation of Supervision Strategy Papers, while the interviews were conducted by the Pansel.

In accordance with the regulations of the Tangerang Regent that in order to implement the provisions of Article 9G, Article 9H, and Article 9l of the Tangerang Regency Regional Regulation Number 1 of 2013 concerning Amendments to the Tangerang Regency's Regional Regulation Number 10 of 2008 concerning the Tirta Kerta Raharja Drinking Water Regional Regulation Tangerang Regency in order to provide legal certainty in terms of requirements, governance the method of carrying out the fit and proper test, the number and position, management and accountability, duties, authorities, 
leave rights and dismissal of the Board of Directors of the Tirta Kerta Raharja Regional Drinking Water Company, Tangerang Regency, it is necessary to stipulate a Regent Regulation concerning the Principal Provisions for the Board of Directors of the Tirta Karya Raharja Regency Water Supply Company. Tangerang;.

Table 1. Potential / Problems from various Aspects

Target Group Potential / Problems from various Aspects

\begin{tabular}{|c|c|}
\hline $\begin{array}{c}\text { Participants will be } \\
\text { candidates for the Board } \\
\text { of Directors of } \\
\text { Perumdam Tangerang } \\
\text { Regency }\end{array}$ & $\begin{array}{l}\text { 1. There are still many prospective candidates for the } \\
\text { Board of Directors who do not know the Feasibility } \\
\text { Test and Fit Test } \\
\text { 2. There are still many candidates for the Board of } \\
\text { Directors who do not know the Technical } \\
\text { Implementation of the Feasibility Test and Fit Test }\end{array}$ \\
\hline
\end{tabular}

Based on Table 1.1 above, community service activities are needed in the form of socialization of the Feasibility Test and Fit Test. The purpose of this socialization is to introduce some of the techniques that will be tested and the readiness of the participants.

\section{Implementation Method}

This service activity begins with the following stages:

1. Administrative terms and conditions

2. Presentation of the Feasibility Test and Fit Test Timline

3. Presentation of the Duties of the Board of Directors

4. Material Reinforcement Fit and Proper

With the following stages:

1) The Supervisory Board as the candidate selection team announced the registration of candidates for directors of PDAM TKR through mass media and the official website (website) of PDAM Tirta Kerta Raharja, Tangerang Regency.

2) Acceptance of registration of candidates for directors of PDAM TKR is carried out within a period of 5 (five) working days.

3) Registrants for candidates for directors of PDAM TKR submit documents

4) The Supervisory Board as the candidate selection team conducts administrative research on the candidates for the directors of PDAM TKR.

5) Results of administrative research on the registration of candidates for directors of PDAM TKR

6) Submitted to prospective directors of PDAM TKR who meet the requirements.

7) The names of prospective directors of PDAM TKR who have passed the administrative research can then take psychological tests and fit and proper tests.

8) Prospective directors of PDAM TKR who get the highest score on the psychological test and fit and proper test can be proposed by the Supervisory Board to the Regent to be appointed and appointed as Directors of PDAM TKR.

9) Appointment stipulated by Tangerang Regent Regulation Number 40 of 2014 


\section{Results and Discussion}

This activity begins with the Feasibility Test and Proper Test Stages after conducting an administrative selection, the presenter describes the stages that will be held:

1. UKK Implementation Time and Place

a. The time is adjusted to the UKK (Uji kelayakan dan Uji kepatutan) implementation schedule set by the Pansel.

b. The place is determined based on the agreement of the Expert Team and the Panel

2. Indicators of weighting stages and value scale

a. UKK assessment indicators include:

1) Company management experience

2) Skill

3) Integrity and Ethics

4) Leadership

5) Understanding of local government administrators; and

6) Have a strong will, high dedication

b. UKK Stages

1) Psychotest

2) Skills written exam

3) Supervision strategy paper writing

4) Supervision strategy paper presentation

5) The interview was conducted by the Pansel. The results of the agreement with the Panel.

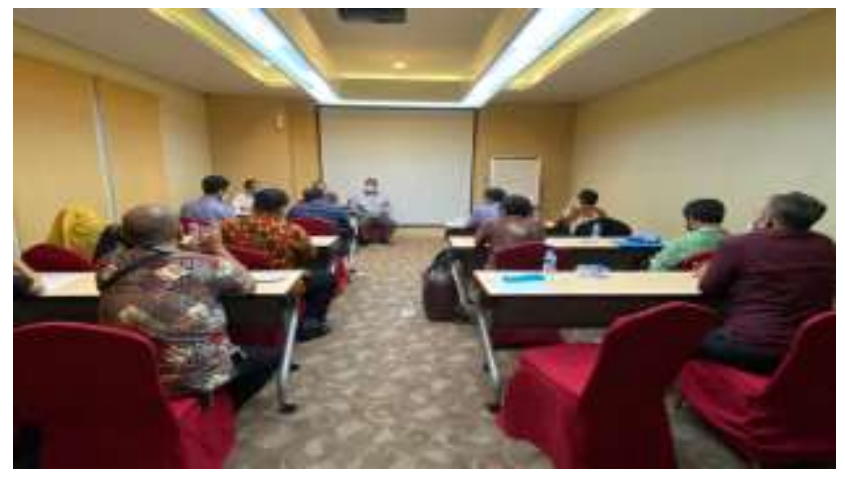

Figure 1. Dissemination of Feasibility Test and Fit Test

c. UKK Weighting and Scale

1) Weighting

$\begin{array}{ll}\text { a) Eligibility } 50 \% & \text { c) Fairness } 30 \%\end{array}$

b) Fairness 30\%

d) Panel Interview 20\%

2) Value Scale

a) Vulnerable Value 1-10

b) Value Classification

- $\quad>8.5=$ Very Satisfactory

- $7.5-8.5=$ Recommended

- $7.0-7.5=$ Recommended with Development

- $\quad<7.0=$ Not Recommended 
3. UKK measurement method

The UKK assessment measurement uses the following approach:

a. Feasibility test

1) Knowledge: understanding the measurement through a written skill test

2) Application: analysis of measurement through writing papers and monitoring strategies

3) Ways of thinking and creating measurement through paper presentations and monitoring strategies

b. Proper test

1) Objective : Written Psychological Examination

2) reactive : Written Psychological Examination

3) Behavioral : Proposal Writing, Semi structured even interview group simulation

\section{Conclusion}

This activity aims to provide socialization and understanding for the participants of the Candidates for the Board of Directors. This activity is one of the independence of a company in appointing new Directors. With the Fit and Proper Test to produce Directors/Leaders who are capable of understanding corporate systems and their psychological fields, this activity not only produces intellectually intelligent leaders but also produces competent leaders in cognitive and emotional functions regarding certain individuals.

Suggestion

This socialization activity is relatively short so that there are still risks that will arise in the future so that there are still participants who still do not understand the technicalities of the Feasibility Test and Fit Test. It is hoped that this socialization will continue before starting the selection stages in various appointments of Prospective Directors.

\section{Acknowledgements}

Thank you to Perumdam Tirta Kerta Raharja Tangerang Regency.

\section{References}

Kosnik R. D, 1990, "Effect of Board Demographic and Director Incentives on Corporate Greenmail Decisions", Academy of Management Journal

lensmetro.com/berita/2021/again-perumdam-tkr

Regulation of The Regent of Tangerang No. 36 year 2014 Concerning The Main Provisions of The Board of Directors of The Regional Drinking Water Company Tirta Kerta Raharja Regency of Tangerang with The Grace of God almighty The Regent of Tangerang,

Shivdasani, A. 1993. Board Composition, Ownership 